\title{
Case report of a patient with a rare location of renal cell carcinoma metastasis
}

\section{Prikaz slučaja pacijentice s rijetkom lokacijom metastaze karcinoma bubrega}

\author{
Damir Grebić ${ }^{1 *}$, Ana Marija Tomasić ${ }^{2}$, Daniel Victor Šimac ${ }^{3}$, Zlatko Kolić ${ }^{4}$, Ana Gavranić \\ David Bonifačić6
}

\begin{abstract}
Aim: Renal cell carcinoma is one of the deadliest cancers which takes the third place among malignant carcinomas of the genitourinary tract. This case report describes the rare case of a large fast-growing metastasis of renal cell cancer in an unusual location with the short time of its appearance, but with an unexpected clinical course after its treatment. Case report: A 60-year-old female patient presented with a fist-sized formation on the scalp. During physical examination, the mass was determined to be firm, infiltrative, fixed, and painless on palpation. The formation had appeared a month prior to arrival, characterized by fast growth. The patient underwent a radical nephrectomy six months earlier due to RCC. A cranial radiogram showed osteolysis of the neurocranium, while an MRI of the brain confirmed the mass belonged to the scalp, no brain infiltration, measuring $82 \times 60 \times 74 \mathrm{~mm}$. Fine needle aspiration isolated malignant cells of an adenocarcinoma, origin undetermined. The patient underwent surgery to remove the mass along with the effected neurocranium, and the resulting bone defect was reconstructed using Palacos. Postoperative recovery went well, and the pathohistological analysis confirmed renal cancer metastasis. PET-CT didn't show suspicious lesions for distal metastasis for a period of 2 years. Conclusion: Renal cell carcinoma commonly metastasizes to the lung. This case report presents the rare case of a large fast-growing renal cancer metastasis to an unusual location, with a short time for metastasis appearance. In spite of that we have shown two years follow up of remission.
\end{abstract}

Key words: neoplasm metastasis; osteolysis; renal cancer

Sažetak. Cilj: Karcinom bubrega zauzima treće mjesto među malignim tumorima genitourinarnog trakta. Cilj je ovog prikaza slučaja je opisati rijedak slučaj gigantske i brzorastuće metastaze ovog karcinoma te rijetko mjesto njezinog sijela s kratkim vremenom njezinog pojavljivanja i neočekivanim kliničkim tijekom nakon njezinog liječenja. Prikaz slučaja: 60-godišnja žena dolazi zbog tvorbe u predjelu mekog oglavka glave veličine šake. Prilikom pregleda tvorba se očitovala kao tvrda infiltrativna, fiksirana za podlogu i palpatorno bezbolna. Tvorba se pojavila mjesec dana pred dolazak te se očitovala vrlo brzim rastom i napredovanjem. Kod pacijentice je šest mjeseci unatrag bila učinjena radikalna nefrektomija zbog karcinoma bubrega. Kraniogram je pokazao osteolizu skeleta neurokranijuma, a MR mozga potvrdio navedeno. Tvorba je pripadala mekom oglavku glave bez infiltracije parenhima mozga i mjerila je $82 \times 60 \times 74 \mathrm{~mm}$. Citološkom punkcijom nađene su maligne stanice adenokarcinoma, ali nije razjašnjeno njihovo podrijetlo. Pacijentica je bila podvrgnuta neurokirurškoj operaciji kojom se uklonila ekspanzivna tvorba uz resekciju skeleta neurokranija, a koštani defekt rekonstruirao se s palakosom. Postoperativni tijek protekao je uredno, a PH nalaz pokazao je da se radilo o metastazi karcinoma bubrega. PET-CT nije pokazao udaljene metastaze u periodu praćenja od dvije godine. Zaključak: Karcinom bubrega najčešće metastazira u pluća. Ovim radom prikazan je rijedak slučaj velike brzorastuće metastaze karcinoma bubrega neobičnog i rijetkog sijela metastaziranja uz kratko vrijeme pojavljivanja metastaze. Unatoč tome kliničkim praćenjem prikazan je period dvije godine remisije.

Ključne riječi: karcinom bubrega; metastaza neoplazme; osteoliza
${ }^{1}$ Department of General and Oncological Surgery, Rijeka Clinical Hospital Center, Faculty of Medicine, Rijeka

${ }^{2}$ Institute of Emergency Medicine, Umag

${ }^{3}$ Department of Hematology, Rheumatology and Clinical Immunology, Rijeka Clinical Hospital Center, Faculty of Medicine, University of Rijeka, Rijeka

${ }^{4}$ Medico Specialty Hospital, Rijeka

${ }^{5}$ Department of Neurosurgery, Rijeka Clinical Hospital Center, Faculty of Medicine, University of Rijeka, Rijeka

${ }^{6}$ Department of Neurology, Rijeka Clinical Hospital Center, Faculty of Medicine, University of Rijeka, Rijeka

\section{*Corresponding author:}

Assist. Prof. Damir Grebić, MD, PhD

Department of General

and Oncological Surgery

Rijeka Clinical Hospital Center

Faculty of Medicine, University of Rijeka

Krešimirova 42, 51000 Rijeka

e-mail: damir.grebic@medri.uniri.hr

http://hrcak.srce.hr/medicina 


\section{INTRODUCTION}

About $2-3 \%$ of malignant tumors in patients are renal cell carcinomas (RCC), representing the third most common genitourinary cancer following bladder and prostate cancers, and the fifth most common cancer in men ${ }^{1,2}$. RCC is among one of the most lethal urological cancers, along with bladder cancer. Incidence of RCC increases $2.5 \%$ annually, due to the frequent use of noninvasive procedures, as well as the influence of genetic and environmental factors ${ }^{3,4}$.

This case report has shown the patient with rare, large, fast-growing metastasis of renal cancer in an unusual location, demonstrating its aggressiveness and high grade. $\mathrm{MRI}$ of the brain confirmed the mass belonged to the scalp with bone osteolysis, but no brain infiltration.

Recent case reports claim $60-70 \%$ of patients with RCC are asymptomatic when diagnosed ${ }^{5}$. The majority of tumors discovered are in an early stage of the disease, and can be treated surgically. Nephrectomy is the gold standard in the treatment of disease that is clinically limited to the kidney, however, due to the aggressive nature and malignancy of RCC, recurrence rates can be as high as $40 \%$ after nephrectomy for localized disease ${ }^{6}$. Approximately $20-30 \%$ of patients have metastatic disease at the time of diagnosis, while $30 \%$ of patients after radical surgery will develop a metastatic disease. Less than $4 \%$ of patients have bilateral tumors, usually within hereditary syndromes ${ }^{7,8}$. Survival rate is well correlated with the TNM stage of disease, serving as the basis for RCC prognosis. Congruently, the 5-year survival rate from stages I to IV decreases respectively from $91 \%, 74 \%$, $67 \%$, to only $32 \%$ for stage IV, in other words, a major decrease in the 5-year survival rate is seen between stage III and IV ${ }^{9}$. RCC is prone to metastasize to almost all soft tissues, with the highest incidence developing in the lung, making up about $16 \%$ of all metastatic localization, followed by bone in about $2-8 \%$ of cases, liver in a maximum of $7 \%$, and the brain in only $4 \%$ of all secondary sites of $\mathrm{RCC}^{10}$. Resection is preferred for solitary lung metastasis, resulting in 5-year survival rates reaching $54 \%{ }^{11}$, resection is also preferred for lo- cal recurrence of disease ${ }^{12}$. With the knowledge of the immune behavior of RCC and its regulatory growth mechanisms, the use of systemic therapy with interleukin-2 (IL-2) has been introduced, contributing to an improved survival rate of $25 \%$ when considering the metastatic stage of disease, although there are many side effects, and development of this type of therapy is still in progress ${ }^{13}$.

The aim of this case report is to describe a rare case of a large fast-growing metastasis of renal cell cancer in an unusual location with a short time of its appearance (six months after nephrectomy), but with the follow up of two years remission after its treatment.

\section{CASE REPORT}

The case of a 60-year-old female patient with RCC is presented. The patient was hospitalized at the Clinic of Urology, Rijeka Clinical Hospital Center, in order to operate the right kidney for a suspected RCC. The first sign of RCC had been discovered during an abdominal ultrasound a month earlier, the ultrasound report described the right kidney as deformed, with inhomogeneous parenchyma, significantly enlarged, measuring approximately $18 \times 11 \mathrm{~cm}$, all other organs normal. Multislice computed tomography (MSCT) of the thorax and abdomen confirmed an enlarged right kidney due to an expansive isodense formation which permeated the majority of the renal parenchyma and sinus, sparing the inferior pole, measuring $15 \times 12 \times$ $9 \mathrm{~cm}(C C \times A P \times L L)$, showing central necrosis during arterial and venous phases, suggesting primarily RCC. Enlarged retroperitoneal and mesenteric lymph nodes, and mediastinal and hilar lymphadenopathy was noted.

After an adequate preoperative preparation, a right-sided radical nephrectomy and adrenectomy were performed via a dorsal lumbotomy incision. A positive lymph node measuring about $5 \mathrm{~cm}$ was also extirpated at the right bifurcation of the internal and external iliac vein. All resected tissue was sent for pathohistological analysis. Further treatment was undertaken in the form of radiotherapy and chemotherapy. Due to the fourth stage of disease, the patient received sunitinib.

The patohistological report identified the right kidney with the ureter, adrenal gland, and perirenal 
fat, as well as the retroperitoneal lymph node among the tissue received. The tumor was localized at the apical and mesorenal parts of the kidney, and infiltrated the renal sinus and perirenal fat. Based on a cross section, the tumor was described as soft in consistency, yellowish, partially cystic and solid, measuring about $13 \times 10 \times 9 \mathrm{~cm}$, with signs of central hemorrhage and necrosis. Histologically, based on the World Health Organization (WHO) Classification of Tumours on Pathology and Genetics of Tumours of the Urinary System and Male Genital Organs, 2004, the tumor cells were determined to originate from renal cells, more precisely identified as a clear cell type renal carcinoma. The tumor was defined as grade II based on the nuclear grading system by Fuhrman. A pseudocapsule was present, which was infiltrated, along with the surrounding fat tissue reaching Gerota's fascia. Microvascular invasion of the tumor was present. It was noted that the tumor did not infiltrate the large muscle veins, nor the renal vein. The surgical margin of the tumor was clear, as well as the renal artery and vein, and the ureter. The adrenal gland presented normal structure. Two lymph nodes found in the perirenal fat tissue and the extirpated retroperitoneal lymph node were completely infiltrated by tumor cells.

The patient returned six months later when a suspicious tumor was noticed on the head in the area above the coronal suture of the skull on the left. A cranial radiogram was immediately taken, the report described an area of osteolysis or destruction of the parietal bone, measuring about $5 \times 3 \mathrm{~cm}$, with irregular edges and intense periosteal reaction. Magnetic resonance imaging (MRI) of the brain confirmed the presence of a subcutaneous expansive process measuring $82 \times$ $60 \times 74 \mathrm{~mm}$ above the coronal suture of the skull on the left with osteolysis and epidural propagation, without infiltration of the brain. All other findings were normal (Figures 1, 2). These findings were highly suspect for metastasis of the earlier operated RCC and fine needle aspiration (FNA) confirmed RCC metastasis.

After imaging, the patient was hospitalized for the second time at the Department of Neurosurgery for the planned surgical treatment of the neurocranial tumor, or solitary RCC metastasis. Neurological status of the patient was normal, and there

were no contraindications for surgical treatment. The patient was operated in the supine position with the head in anteflexion at about 20 degrees and fixed in a Mayfield head clamp (Figure 3). The skin covering the tumor was excised in a "teardrop" shape revealing a limited soft tissue mass which was removed and sent for pathohistological analysis (Figure 4). After removing the tumor, partially destroyed frontal and parietal bones to the left of the median line were noticed, and a frontoparietal craniectomy was performed, removing the effected bone, which was sent for pathohistological analysis as well (Figure 5). Dura mater was

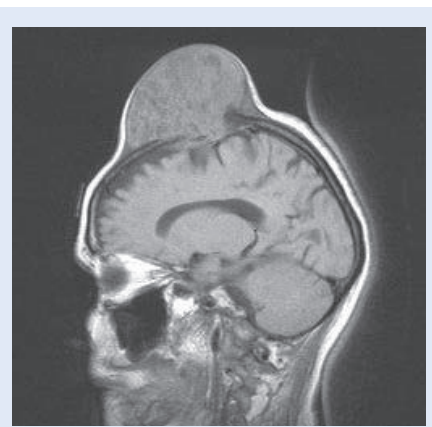

Figure 1. MRI brain scan, sagittal cross section. The tumorous mass of the scalp is seen with osteolysis of the parietal bone, and propagation to the dura mater. Brain parenchyma is normal.

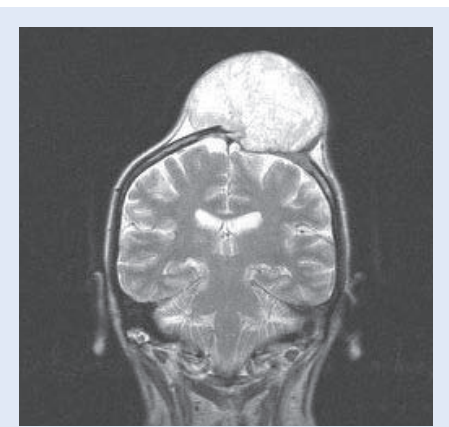

Figure 2. MRI brain scan, coronal cross section. The tumorous mass of the scalp is seen with osteolysis of the adjacent neurocranium. Intracranial propagation is not visualized.

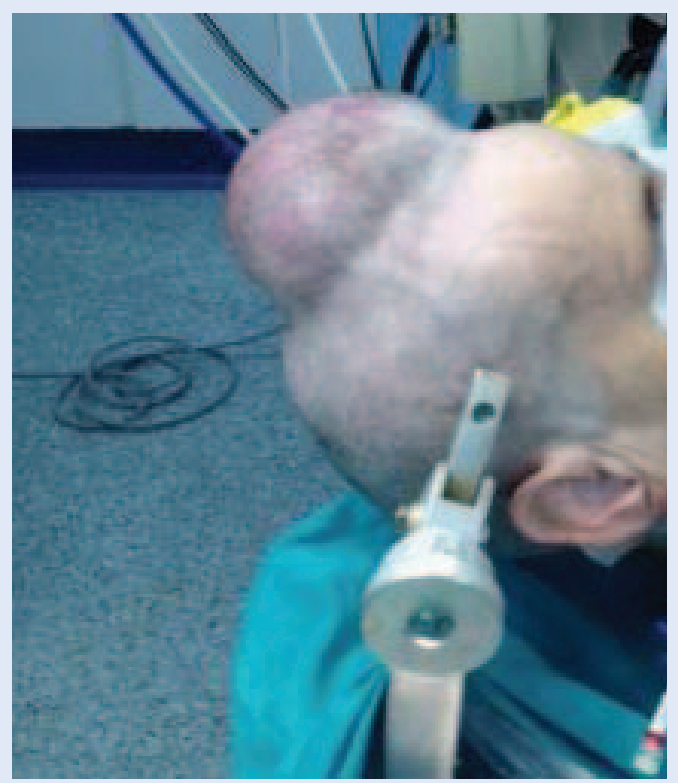

Figure 3. Preparation of the patient in the operating room for neurosurgery. A large tumorous mass of the parietal region is clinically seen, about $8 \mathrm{~cm}$ in diameter, firm, fixed, and painless when palpated. 


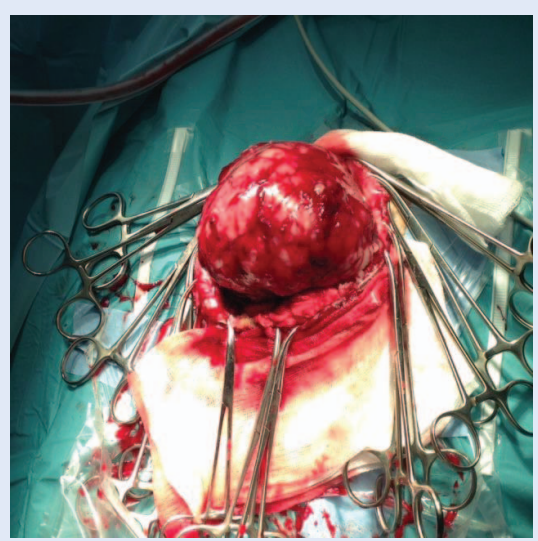

Figure 4. Operation. After removing the skin and part of the subcutaneous tissue of the scalp, the tumorous mass is seen.

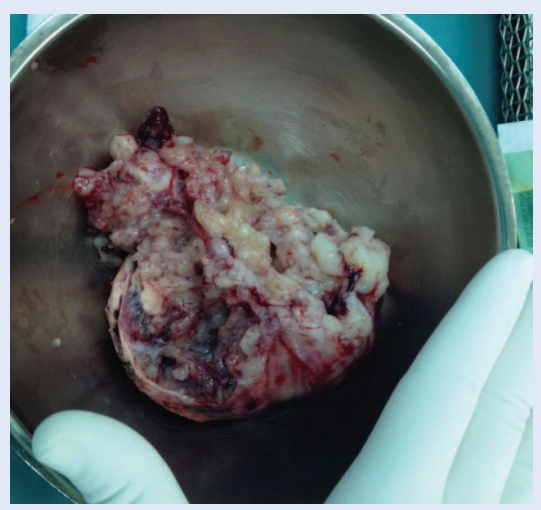

Figure 5. Extirpated tumor. The tumor along with the resected section of osteolytic parietal bone is shown. The pathohistological report confirmed a RCC metastasis.

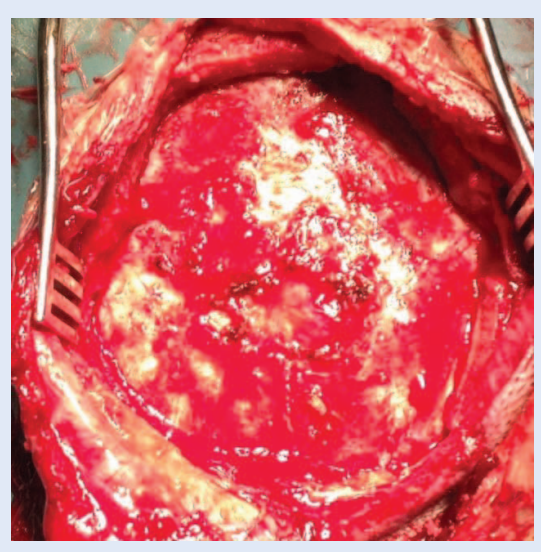

Figure 6. Postoperative defect. The bone defect after the extirpation of the tumor of the scalp with the parietal bone was reconstructed using Palacos.
After surgery the final pathohistological examination confirmed renal cancer metastasis. After imaging no suspicious lesions have been shown for a follow-up period of 2 years. It should be noted that every lesion should be suspected as metastasis in renal cancer patients due to its aggressiveness and unpredictable behavior.

intact. Surgicel, a hemostatic agent, and supportive sutures were applied to the craniectomy margins (Figure 6). Perforated Palacos, a bone cement, was used for cranioplasty, after which the surgical wound was closed and sutured (Figure 7).

The pathohistological report described a tumorous mass of lobular and solid structure, measuring $10 \times 8 \times 4 \mathrm{~cm}$, consistent with the structure of

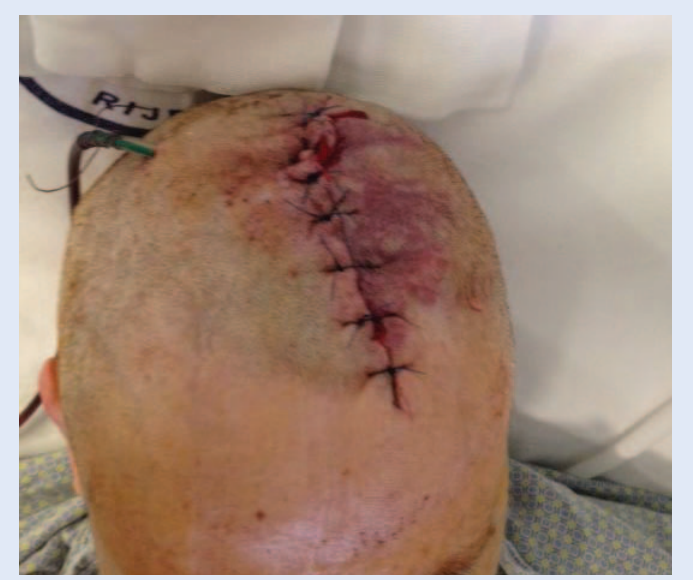

Figure 7. End of operation. The sutured surgical wound with a Redon drain is shown. the tissue received earlier identifying RCC, clear cell type, grade III.

Postoperative recovery passed without complications. The surgical wound healed per primam without complications. The patient was discharged on the seventh postoperative day in good overall health. The surgical drain was removed on the tenth postoperative day due to the prolonged drainage from the wound, along with the stitches. A thoracic radiogram and positron emission tomography combined with computed tomography (PET-CT) were ordered to asses for distal metastases, neither of which showed any suspicious lesions in the lungs or other organs for a follow-up period of 2 years.

\section{DISCUSSION}

RCC is a complex cancer that requires a complex approach, namely due to its aggressive and unpredictable behavior, and a propensity to metasta$\mathrm{size}^{14}$. Rare or unusual locations of RCC metastases are defined as the sites anatomically distant from the kidney or outside of the typical path of metastatic spread of renal tumors. When breaking down the occurrences of RCC metastatic locations to percentages, the numbers vary considerably, as a result, there are several case reports presenting rare metastatic sites ${ }^{15}$. The mean time for appearance of metastasis of RCC is 1-2 years after operation $^{16}$ although in the literature there is a case report with record lung metastasis from RCC 37 years after nephrectomy ${ }^{17}$. When compared to this 
our patient had a very early appearance of metastatic disease even received sunitinib treatment that should decrease the relapse of disease ${ }^{18}$. On the other side there were very interesting two years of remission after radical resection of solitary metastatic laesion with no signs for distal metastatic disease in PET-CT examination ${ }^{19}$.

Our patient underwent radical nephrectomy, after which intact surgical margins were confirmed, as well as adrenal gland and ureter.

The possibility of local recurrence of disease was considerably greater in this case than the occurrence of distant metastases due to patohistologically confirmed capsule infiltration and lymphovascular invasion with positive lymph nodes ${ }^{6}$. In spite of this, in the six months following nephrectomy, the patient developed a large solitary RCC metastasis in the subcutaneous tissue of the scalp with osteolysis and periostatic reaction of the underlying cranium, which is the first such case seen in our clinic, which correlates with the low incidence of RCC metastasis in this location as described earlier. Stage IV RCC has a 5-year survival rate of only $32 \%$, our patient after successful removal of the scalp metastasis, had a two year follow up without lung or other metastases ${ }^{9}$. Follow up after radical nephrectomy treatment of RCC, which includes thorough anamnesis, clinical examination, and diagnostic procedures like PET-CT and MRI scans to detect possible metastases, is the key for prompt and adequate treatment, as shown in the case of our patient ${ }^{19}$.

\section{CONCLUSION}

In conclusion, RCC commonly metastasizes to the lung. This case report presents the rare case of a large fast-growing RCC metastasis to an unusual location, demonstrating its aggressiveness and high grade. In spite of that we showed two years follow up of remission. It should be noted that every lesion should be suspected as metastasis in RCC patients, confirmed via pathohistological analysis.

Conflicts of interest statement: the authors report no conflicts of interest.

\section{REFERENCES}

1. Jemal A, Siegel R, Ward E, Hao Y, Xu J, Thun MJ. Cancer statistics 2009. CA Cancer J Clin 2009;59:225-49.
2. Heidenreich A, Ravery V. Preoperative imaging in renal cell cancer. World J Urol 2004;22:307-15.

3. Chow WH, Devesa SS, Warren JL, Fraumeni JF Jr. Rising incidence of renal cell cancer in the United States. JAMA 1999;281:1628-31.

4. Lam JS, Belldegrun AS, Pantuck AJ. Long-term outcomes of the surgical management of renal cell carcinoma. World J Urol 2006;24:255-66.

5. Parsons JK, Schoenberg MS, Carter HB. Incidental renal tumors: casting doubt on the efficacy of early intervention. Urology 2001;57:1013-5.

6. Janzen NK, Kim HL, Figlin RA, Belldegrun AS. Surveillance after radical or partial nephrectomy for localized renal cell carcinoma and management of recurrent disease. Urol Clin North Am 2003;30:843-52.

7. Hock LM, Lynch J, Balaji KC. Increasing incidence of all stages of kidney cancer in the last 2 decades in the United States: an analysis of surveillance, epidemiology and end results program data. J Urol 2002;167:57-60.

8. Zisman A, Pantuck AJ, Wieder J, Chao DH, Dorey F, Said JW et al. Risk group assessment and clinical outcome algorithm to predict the natural history of patients with surgically resected rena cell carcinoma. J Clin Oncol 2002;20:4559-66.

9. Tsui KH, Shvarts O, Smith RB, Figlin RA, deKernion JB, BeIldegrun A. Prognostic indicators for renal cell carcinoma: a multivariate analysis of 643 patients using the revised 1997 TNM staging criteria. J Urol 2000; 163:1090-5.

10. Chin Al, Lam JS, Figlin RA, Belldegrun AS. Surveillance strategies for renal cell carcinoma patients following nephrectomy. Rev Urol 2006;8:1-7.

11. Piltz S, Meimarakis G, Wichmann MW, Hatz R, Schildberg FW, Fuerst $\mathrm{H}$. Long-term results after pulmonary resection of renal cell carcinoma metastases. Ann Thorac Surg 2002;73:1082-7.

12. Itano NB, Blute ML, Spotts B, Zincke H. Outcome of isolated renal cell carcinoma fossa recurrence after nephrectomy. J Urol 2000;164:322-5.

13. Lam JS, Belldegrun AS, Figlin RA. Advances in immunebased therapies of renal cell carcinoma. Expert Rev Anticancer Ther 2004;4:1081-96.

14. Gaur K, Mandal S, Gondal R, Singh D. Atypical presentation of calvarial metastasis of renal cell carcinoma in an adolescent: a rare case diagnosed on fine needle aspiration cytology with literature review. Diagn Cytopathol 2015;43:412-5.

15. Sountoulides P, Metaxa L, Cindolo L. Atypical presentations and rare metastatic sites of renal cell carcinoma: a review of case reports. J Med Case Rep 2011; 5:429.

16. Motzer RJ, Agarwal N, Beard C, Bolger GB, Boston B, Carducci MA et al. NCCN clinical practice guidelines in oncology: kidney cancer. J Natl Compr Canc Netw 2009;7:618-30.

17. Tamburrini A, Majorino A, Duggan S, Jogai S, Alzetani A. A record-breaking lung metastasis from renal cell carcinoma 37 years after nephrectomy. J Surg Case Rep 2017;2017:rjx205.

18. Motzer RJ, Hutson TE, Tomczak P, Michaelson MD, Bukowski RM, Oudard S et al. Overall survival and updated results for sunitinib compared with interferon alfa in patients with metastatic renal cell carcinoma. J Clin Oncol 2009;27:3584-90.

19. Donat SM, Diaz M, Bishoff JT, Coleman JA, Dahm P, Derweesh IH et al. Follow-up for clinically localized renal neoplasms: AUA Guideline. J Urol 2013;190:407-16. 